\title{
KONSUMSI BAHAN KERING DAN KECERNAAN CALCIUM, PHOSPHOR PAKAN LOKAL DAN IMPOR PADA ANAK KUDA PACU INDONESIA
}

\author{
Gabriela Nangin, Y.L.R Tulung*, R.A.V. Tuturoong, A. Rumambi \\ Fakultas Peternakan Universitas Sam Ratulangi Manado 95115
}

\begin{abstract}
ABSTRAK
Penelitian ini bertujuan untuk mengetahui kemampuan anak kuda pacu dalam mengkonsumsi dan mencerna pakan, baik pakan lokal dan pakan impor. Penelitian ini dilaksanakan di Desa Pinabetengan Kecamatan. Tompaso. Selama 30 hari terdiri dari persiapan dan pengumpulan data. Data yang dikumpulkan yaitu jenis dan jumlah pakan yang diberikan pada anak kuda pacu serta jumlah feses $\left(\right.$ ekor $^{-1} \cdot$ hari $\left.^{-1}\right)$. Ternak yang digunakan berjumlah 17 ekor berumur 12-16 bulan, dimana 9 anak kuda pacu mengkonsumsi pakan lokal dan 8 anak kuda pacu mengkonsumsi pakan impor. Variabel yang diukur adalah kecernaan $\mathrm{Ca}$ dan $\mathrm{P}$. Data hasil penelitian dianalisis statistik dengan menggunakan uji t-Test: Two-Sample Assuming Unequal Variances. Hasil uji ttest menunjukan bahwa ternyata kecernaan $\mathrm{Ca}$ pakan impor $1,22 \%$ berbeda nyata $(\mathrm{p}<0.05)$ dibandingkan dengan pakan lokal $0,82 \%$, begitu juga dengan kecernaan $\mathrm{P}$ pakan impor $0,68 \%$ berbeda nyata dibanding dengan pakan local 0.56. Berdasarkan hasil penelitian ini, dapat disimpulkan bahwa kecernaan $\mathrm{Ca}$ dan $\mathrm{P}$ untuk pakan impor lebih baik dibandingkan dengan pakan lokal.
\end{abstract}

Kata kunci: anak kuda pacu, Pakan lokal, Pakan impor, Kecernaan Ca dan P

*Korespondensi (corresponding Author):

Email: tulungyohannis@gmail.com
ABSTRACT

DRY MATTER CONSUMPTION AND THE DIGESTIBILITY OF CALCIUM AND PHOSPHORUS IN BOTH LOCAL AND IMPORTED FEED FOR RACER FOAL OF INDONESIA. The purpose of this study to determine the ability of foal to the consume and digest both local feed and imported feed. This study was carried out in the Pinabetengan village, Tompaso district, for 30 days During these days preparation and data collection was carried out. The object of the study was the foal's feed, either the amount or the type of it, and the foal's feces. There were seventeen foal's for the object of this study. Divided into two groups. First group contained nine foal's consuming local feed and the other group contained eight foal's consuming imported feed. The variable measured was the digestibility $\mathrm{Ca}$ and $\mathrm{P}$. The study analyzed statistically using t-Test method: TwoSample Assuming Unequal Variances. The result of this study using t-Test method indicated that the digestibility $\mathrm{Ca}$ of imported feed 1.220 .82 was significantly higher $\mathrm{p}<0,05$ than the local feed, as well as in the digestibility $\mathrm{P}$ of import feed 0,68 0,56 . Based on the result of this study, it can be concluded that the digestibility of $\mathrm{Ca}$ and $\mathrm{P}$ for imported feed is better than the digestibility of $\mathrm{Ca}$ an $\mathrm{P}$ for local feed.

Keywords: Racer foal, Local feed, Imported feed, Digestibility of Ca dan P 


\section{PENDAHULUAN}

Anak kuda pacu adalah ternak yang potensial untuk dikembangkan sebagai unit usaha. Nilai jual anak kuda tidak hanya ditentukan dari bobot badan melainkan juga dari pedigree ternak dan prestasinya, sehingga harga anak kuda relatif lebih mahal dari harga ternak yang dibudidayakan untuk konsumsi. Beberapa anak kuda dipelihara intensif untuk berbagai tujuan yaitu sebagai kuda pacu, kuda tunggang, dan sebagai alat transportasi. Anak kuda pacu Indonesia umumnya merupakan jenis kuda lokal yang bertubuh kecil. Postur tubuh kuda ini masih jauh dari standar untuk digunakan sebagai kuda olahraga apalagi untuk pacuan. Usaha untuk memperbaiki mutu anak kuda pacu Indonesia menjadi suatu kajian yang kemudian peternak mengusulkan kepada Pordasi (persatuan olahraga berkuda seluruh Indonesia) pada tahun 1974 untuk mendatangkan pejantan thoroughbred dan disilangkan dengan kuda lokal. Manajemen pemeliharaan dan pemberian pakan serta kandungan nutrisi pakan menjadi faktor penentu dari peforma anak kuda pacu selain dari kualitas genetik yang dimilikinya. Anak kuda pacu dengan tata laksana pemberian pakan yang baik secara kualitas maupun kuantitasnya akan memiliki rangka yang kokoh dan mengalami pertumbuhan yang normal. Indonesia merupakan negara agraris dimana bahan baku pakan lokal berupa biji-bijian dan hijauan cukup tersedia dan berkualitas baik. Kebutuhan nutrisi pakan anak kuda pacu umur 12-16 bulan berdasarkan bahan kering yaitu protein kasar Ca dan $\mathrm{P}$ yang masing-masing adalah 12,6 0,52 dan 0,08 (NRC, 1989).

Tujuan dari pemeliharaan anak kuda pacu adalah untuk mendapatkan kuda yang baik dan siap ketika diikut sertakan untuk lomba. Oleh karena itu untuk mengetahui tingkat kecernaan Ca dan $\mathrm{P}$ pakan lokal dan impor pada anak kuda pacu Indonesia perlu dilakukan penelitian.

\section{MATERI DAN METODE PENELITIAN}

Penelitian ini telah dilaksanakan di Desa Tompaso Kecamatan Tompaso sejak bulan Januari-Februari 2017. Penelitian ini menggunakan anak kuda pacu hasil persilangan kuda lokal dengan kuda thoroughbred berumur 12-16 bulan sebanyak 17 anak kuda pacu, 9 anak kuda pacu yang mengkonsumsi pakan lokal, dan 8 anak kuda pacu mengkonsumsi pakan impor yang masing-masing mengkonsumsi hijauan dan konsentrat.

Data yang dikumpulkan adalah jumlah pakan lokal dan impor yang dikonsumsi (hijauan dan konsentrat). Cara pengambilan data dengan menimbang 
pakan lokal dan pakan impor yang akan diberikan pada masing-masing anak kuda pacu. Data pengambilan feses (g.ekor ${ }^{1}$.hari $\left.{ }^{-1}\right)$. Pengambilan data feses dengan cara mengumpulkan feses setiap hari pada waktu devikasi, kemudian ditimbang dan dijemur, setelah feses kering selanjutnya feses dikompositkan dan digiling, masingmasing dari setiap sampel feses pakan lokal dan impor diambil sebanyak 100g untuk dianalisis.

Alat yang digunakan dalam penelitian ini yaitu, Timbangan, kantong plastik, alat tulis menulis, aluminium voil dan sarung tangan. Variabel yang diamati dalam penelitian adalah : Kecernaan Ca dan $\mathrm{P}$.

Kecernaan Ca dan $\mathrm{P}$ dihitung berdasarkan rumus (Banerjee,1978):

Koefisien cerna Ca ransum perlakuan (KCCa) dihitung sebagai berikut:

\begin{tabular}{|c|c|c|}
\hline $\mathrm{KCCa}$ & $=$ & $($ Kons $R x \%$ CaR $)$ \\
\hline \multicolumn{3}{|l|}{$\begin{array}{l}\mathrm{x} 100 \% \\
\text { dimana: }\end{array}$} \\
\hline & $\mathrm{KCCa}$ & $\begin{array}{c}\text { : Koefisien cerna semu Ca kasar ransum } \\
(\%)\end{array}$ \\
\hline & Kons R & $\begin{array}{l}\text { : Jumlah ransum perlakuan yang } \\
\text { dikonsumsi }\left(\text { g.ekor }^{-1} \text {.hari }{ }^{-1}\right)\end{array}$ \\
\hline & $\mathrm{CaR}$ & : Ca kasar ransum $(\%)$ \\
\hline & $\sum$ fes & $\begin{array}{l}\text { : Jumlah feses yang didefikasi (g.ekor } \\
{ }^{1} \text {.hari }^{-1} \text { ) }\end{array}$ \\
\hline & $\% \mathrm{Ca}$ fes & : Ca feses $(\%)$ \\
\hline
\end{tabular}

Koefisien cerna $\mathrm{P}$ ransum perlakuan $(\mathrm{KCP})$ dihitung sebagai berikut:

$$
\begin{aligned}
& \mathrm{KCP}=\frac{(\text { Kons.R } x \% P R)-\left(\sum \text { fes } x \% P \text { fes }\right)}{(\text { Kons Rx\% } \% R)} \times 100 \% \\
& \text { dimana: } \\
& \text { KCP : Koefisien cerna semu P ransum (\%) } \\
& \text { Kons } \mathrm{R} \text { : Jumlah ransum perlakuan yang dikonsumsi } \\
& \text { (g.ekor } \left.{ }^{-1} \cdot \text { hari }^{-1}\right) \\
& \text { P R : P ransum (\%) } \\
& \sum \text { feses : Jumlah feses yang didefikasi }\left(\text { g.ekor }^{-1} \text {.hari }{ }^{-1}\right) \\
& \% \text { Pfes } \quad: \text { P feses }(\%) \text {. }
\end{aligned}
$$

Penelitian ini menggunakan metode eksperimen. Teknik pengambilan data yaitu wawancara dan pengamatan dan pengambilan langsung melalui metode koleksi total dilokasi peternak anak kuda pacu. Data hasil penelitian dianalisis dengan menggunakan uji t-Test : TwoSample Assuming Unequal Variances.

\section{HASIL DAN PEMBAHASAN}

\section{Pengaruh Perlakuan Terhadap Konsumsi Bahan Kering Pakan}

Rataan nilai konsumsi bahan kering pakan lokal dan pakan impor tercantum pada Tabel 1. Hasil analisis data yang dilakukan, terdapat perbedaan antara konsumsi pakan lokal dan pakan impor. Berdasarkan hasil uji t, pakan lokal berbeda nyata lebih tinggi $(\mathrm{P}<0,05)$ dibandingkan dengan pakan impor. Rataan nilai konsumsi pakan lokal lebih tinggi 5.498,72 g dari pakan impor 5.316,65 g. Penelitian ini lebih rendah dari penelitian Mamahit et al. (2019), pada anak kuda pacu umur 13-24 bulan, memperoleh konsumsi pakan lokal $5.816 \mathrm{~g}$ dan pakan impor 6.411 g. Walaupun dari jumlah konsumsi pakan lokal lebih tinggi dibandingkan dengan pakan impor akan tetapi dari segi nilai biologis pakan lokal lebih rendah dibandingkan dengan pakan impor. Sesuai dengan yang dikemukakan oleh Tulung (2012), bahwa nilai biologis pakan lokal lebih rendah dibandingkan dengan pakan 
impor, walaupun jumlah konsumsi bahan kering pakan lokal lebih banyak dibandingkan pakan impor, akan tetapi hanya sedikit yang dapat digunakan. Menurut Mende et al. (2015) ada beberapa faktor yang harus diperhatikan dalam pemberian pakan pada anak kuda pacu yaitu bentuk pakan, umur pakan, dan hijauan yang akan diberikan. Demikian juga Susan and Shoveller (2008) membandingkan bentuk fisik bahan baku lokal pakan biji-bijian dengan gandum impor, tetapi struktur butirannya lebih kasar dari pada gandum. Selanjutnya dikatakan Guay et al. (2002) untuk mendapatkan performa kuda yang bagus perlu adanya evaluasi dan penentuan kualitas pakan anak kuda pacu.

Rataan kecernaan Ca dan P anak kuda pacu ditampilkan pada Tabel. 1

\section{Pengaruh Perlakuan Terhadap Kecernaan Ca}

Rataan nilai kecernaan Ca pakan lokal dan pakan impor pada Tabel 1 ternyata kecernaan $\mathrm{Ca}$ pakan impor lebih tinggi dibandingkan dengan pakan lokal. Hasil analisis t-Test: Two-Sample Assuming Unequal Variances, dilihat dari angka, kecernaa $\mathrm{Ca}$ pakan impor berbeda nyata lebih tinggi $\mathrm{P}<0,05$ dibandingkan dengan pakan lokal. Hal ini disebabkan karena kandungan Ca pakan impor lebih tinggi dari pakan lokal. $\mathrm{Ca}$ mempunyai peranan penting dalam aktivitas fisiologi beberapa sel seperti pembentukan tulang, kontraksi otot, dan metabolisme tubuh (Peacock, 2010). Sekitar $99 \%$ Ca terdapat di kerangka dan sisanya $1 \%$ didistribusikan di cairan ekstraseluler (Boros et al., 2009). Kebutuhan $\mathrm{Ca}$ pada masa pertumbuhan anak kuda pacu harus benar diperhatikan, karena $\mathrm{Ca}$ merupakan mineral yang paling banyak dibutuhkan oleh ternak dan berperan penting sebagai penyusun tulang, (McDonald et al., 2010). Ini sama halnya dengan yang dikatakan El-Samad et al. (2002), bahwa Ca berperan penting dalam mempertahankan struktur tulang.

Tabel. 1 Rataan Jumlah Konsumsi Bahan Kering dan Kecernaan Ca, P Pakan Lokal dan Impor

\begin{tabular}{lcc}
\hline & Pakan Lokal & Pakan Impor \\
\hline Konsumsi g & 5498,72 & 5316,65 \\
Kecernaan Ca $(\%)$ & $0,82^{\mathrm{a}}$ & $1.22^{\mathrm{b}}$ \\
Kecernaan P $(\%)$ & $0,56^{\mathrm{a}}$ & $0,68^{\mathrm{b}}$ \\
\hline
\end{tabular}

Keterangan: Superskrip yang berbeda pada baris yang sama menunjukkan perbedaan nyata $(\mathrm{P}<0,01)$ 
Kandungan $\mathrm{Ca}$ yang normal dibutuhkan untuk beberapa proses metabolisme tertentu, jika kebutuhan Ca tidak terpenuhi maka $\mathrm{Ca}$ yang ada dalam tulang akan dimobilisasi. Dari hasil penelitian juga menunjukkan bahwa rendahnya kadar $\mathrm{Ca}$, dapat menyebabkan timbulnya penyakit seperti abnormalitas tulang (Bindari et al., 2013).

Ca dan P memiliki kaitan yang sangat erat satu sama lain dalam proses metabolisme pada anak kuda pacu. Oleh sebab itu kandungan mineral $\mathrm{Ca}$ dan $\mathrm{P}$ dalam pakan harus benar-benar seimbang yakni 2:1 (Richard et al., 2006). Keseimbangan rasio antara $\mathrm{Ca}$; $\mathrm{P}$ diperlukan untuk memelihara kesehatan anak kuda pacu.. Kebutuhan $\mathrm{Ca}$ dan $\mathrm{P}$ masing-masing adalah 0,52 dan 0,08 (NRC, 2007).

\section{Pengaruh Perlakuan Terhadap Kecernaan $\mathbf{P}$}

Rataan nilai kecernaan P pakan lokal dan pakan impor pada Tabel. 1 diatas terlihat bahwa, nilai kecernaan $\mathrm{P}$ pakan impor lebih tinggi dibandingkan dengan pakan lokal. Hasil analisis t-Test: TwoSample Assuming Unequal Variances, menunjukan bahwa nilai kecernaan $\mathrm{P}$ pakan impor berbeda nyata lebih tinggi $\mathrm{P}<0.05$ dibandingkan dengan pakan lokal. Hal ini disebabkan karena kandungan $\mathrm{P}$ pakan impor lebih tinggi dari pakan lokal.
$\mathrm{P}$ memiliki peran biokimia dan fisiologis yang sangat penting dan merupakan mineral terbanyak dalam tubuh setelah Ca. Sekitar 80 - 85\% terdapat dalam tulang dan $15-20 \%$ berada dalam jaringan lunak (Greisert et al., 2010). Kebutuhan mineral $\mathrm{P}$ harus diperhatikan karena defisiensi mineral ini berpengaruh pada kesehatan anak kuda pacu (Stanley et al., 2007). Kandungan mineral $\mathrm{Ca}$ dan $\mathrm{P}$ dalam pakan harus benar-benar seimbang yakni 2:1 (Richard et al., 2006).

$P$ juga berperan penting dalam perkembangan dan metabolisme anak kuda pacu (Alfaro et al., 1988). Dalam program pemberian pakan hijauan perlu dikombinasikan dengan konsentrat menggunakan formulasi yang baik, agar mineral dan vitamin tersedia cukup untuk memenuhi kebutuhan anak kuda pacu (Williams dan Burk, 2010). Anak kuda pacu juga membutuhkan pakan tambahan berupa vitamin dan mineral dalam pakan, karena vitamin dan mineral merupakan feed supplemen maupun feed additive untuk melengkapi kekurangan nutrisi dalam pakan anak kuda pacu (Firth, 2004).

\section{KESIMPULAN}

Berdasarkan hasil penelitian dan pembahasan dapat disimpulkan bahwa nilai kecernaan $\mathrm{Ca}$ dan $\mathrm{P}$ untuk pakan impor lebih baik dibandingkan dengan pakan 
lokal, karena kandungan $\mathrm{Ca}$ dan $\mathrm{P}$ pakan

impor lebih tinggi dari pakan lokal.

\section{DAFTAR PUSTAKA}

Alfaro, E., M.W. Neathery, W.J. Miller, C.T. Crowe, R.P. Gentry, A.S. Fielding, dan D.M. Blackmon. 1988. Influence of a wide range of calcium intakes on tissue distribution of macroelements and microelements in dairy calves. Journal of Dairy Science 71(5): 1295-1300.

Banerjee, S.K. 1978. Animal Nutrition. Oxford LBH Publ. Co. Calcutta. Bombay. New Delhi.

Bindari, Y. R., S. Shrestha, N. Shrestha, dan T.N. Gaire. 2013. Effects of nutrition on reproduction-A review. Adv. Appl. Sci. Res. 4(1): 421-429.

Boros, S., R.J. Bindels, dan J. Hoenderop. 2009. Active $\mathrm{Ca} 2+$ reabsorption in the connecting tubule. Pflügers Archiv-European Journal of Physiology 458(1): 99-109.

El-Samad, H., J.P. Goff, dan M. Khammash. 2002. Calcium homeostasis and parturient hypocalcemia: an integral feedback perspective. Journal of theoretical biology 214(1): 17-29.

Firth, E. C. 2006. The response of bone, articular cartilage and tendon to exercise in the horse. Journal of Anatomy 208(4): 513-526.

Geisert, B. G., G.E. Erickson, T.J. Klopfenstein, C.N. Macken, M.K. Luebbe, dan J.C. MacDonald. 2010. Phosphorus requirement and excretion of finishing beef cattle fed different concentrations of phosphorus. Journal of Animal Science 88(7): 2393-2402.

Guay, K. A., H.A. Brady, V.G. Allen, K.R. Pond, D.B. Wester, L.A. Janecka, dan N.L. Heninger. 2002. Matua bromegrass hay for mares in gestation and lactation. Journal of Animal Science 80(11): 29602966.

Mamahit. K., Y.L.R. Tulung, C.A. Rahasia, S.A.E. Moningkey. 2019 Kecernaan lemak dan serat kasar pakan anak kuda pacu (Yearling) Indonesia yang diberi pakan penguat lokal dan impor. Zootec 39(1): 146 - 154

McDonald, P., R.A. Edwards, dan J.F.D. Greenhalgh, C.A. Morgan, L.A. Sinclair, and R.G. Wilkinson. 2010. Animal Nutrition 7th ed. Longman Group UK Ltd, England. 693p.

Mende, I. S., Tulung, Y. L. R., Umboh, J. F., \& Kaunang, W. B. (2015). Kecernaan energi, protein, dan mineral kalsium dan fosfor kuda pacu minahasa yang diberi pakan lokal dan impor. Zootec 35(1): 3038.

NRC. 1989. 5th Revised ed. National Academy Press. Washington DC.

NRC. 2007. Nutrient Requirements Of Small Ruminants: Sheep, goats, cervids and new world camelids. Press, Washington, USA.

Peacock, M. 2010. Calcium metabolism in health and disease. Clinical Journal of the American Society of Nephrology, 5(Supplement 1), S23S30.

Richards, N., Hinch, G. N., \& Rowe, J. B. 2006. The effect of current grain feeding practices on hindgut starch 
fermentation and acidosis in the Australian racing Thouroughbred. Australian Veterinary Journal 84(11): 402-407.

Susan, N. dan A. K. Shoveller. 2008. Nutrition and Feeding Management For Horse Owners. Alberta Agriculture and Rural Development in Canada.

Stanley, R.L., R.A. Fleck, D.L. Becker, A.E. Goodship, J.R. Ralphs, dan J.C. Patterson-Kane. 2007. Gap junction protein expression and cellularity: comparison of immature and adult equine digital tendons. Journal of

Anatomy 211(3): 325-334

Tulung, Y. L. R. 2012. Kebutuhan Energi dan Nutrien Kuda Pacu Indonesiadan Aplikasi pada Formulasi Ransum Berbasis Pakan Lokal. Disertasi. Program Pascasarjana, Institut Pertanian Bogor. Bogor

Williams, C. A. dan A. Burk. 2010. Feeding Management of The Three-Day Event Horse. In Kentucky Equine Research Nutrition Conference. Lexington, Kentucky (pp. 120126). 